Géographie physique et Quaternaire

Middle Wisconsinan Mammals, Stratigraphy, and Sedimentology at the Ketza River Site, Yukon Territory

Mammifères, stratigraphie et sédimentologie du Wisconsinien moyen au site de Ketza River, Yukon

Sâugetier-Stratigraphie und Sédimentologie im Wisconsinium am Ketza River, Yukon Territory

Lionel E. Jackson et C. Richard Harington

Volume 45, numéro 1, 1991

URI : https://id.erudit.org/iderudit/032846ar

DOI : https://doi.org/10.7202/032846ar

Aller au sommaire du numéro

Éditeur(s)

Les Presses de l'Université de Montréal

ISSN

0705-7199 (imprimé)

1492-143X (numérique)

Découvrir la revue

Citer cet article

Jackson, L. E. \& Harington, C. R. (1991). Middle Wisconsinan Mammals, Stratigraphy, and Sedimentology at the Ketza River Site, Yukon Territory. Géographie physique et Quaternaire, 45(1), 69-77.

https://doi.org/10.7202/032846ar
Résumé de l'article

Les restes de mammouth, de bison, de cheval, d'orignal, de lièvre, d'écureuil et de lemming ont été recueillis dans des sédiments sous-jacents au till de la Glaciation de McConnell du Wisconsinien supérieur, le long de la vallée de Ketza. Les sédiments renfermant ces ossements représentent un complexe de colluvions, d'alluvions et de sédiments fluvio-glaciaires. D'autres sites fossilifères risquent de se trouver là où les cours d'eau fluvio-glaciaires traversent des colluvions déposées avant le début de la Glaciation de McConnell. 


\section{MIDDLE WISCONSINAN MAMMALS, STRATIGRAPHY, AND SEDIMENTOLOGY AT THE KETZA RIVER SITE, YUKON TERRITORY*}

Lionel E. JACKSON, Jr, and C. Richard HARINGTON, Geological Survey of Canada, 100 West Pender Street, Vancouver, British Columbia V6B 1R8, and Canadian Museum of Nature, Paleobiology, Ottawa, Ontario K1P 6P4.

ABSTRACT Remains of Middle Wisconsinan mammoth, bison, horse, moose, hare, ground squirrel and lemming were recovered from sediments that stratigraphically underlie till of the Late Wisconsinan McConnell Glaciation along the Ketza River valley. The bone-bearing sediments are a complex of colluvium, fan, and outwash sediments. Similar fossil sites are likely to occur where glaciofluvial watercourses abut hillside deposits laid down prior to the onset of McConnell Glaciation.
RÉSUMÉ Mammifères, stratigraphie et sédimentologie du Wisconsinien moyen au site de Ketza River, Yukon. Les restes de mammouth, de bison, de cheval, d'orignal, de lièvre, d'écureuil et de lemming ont été recueillis dans des sédiments sous-jacents au till de la Glaciation de McConnell du Wisconsinien supérieur, le long de la vallée de Ketza. Les sédiments renfermant ces ossements représentent un complexe de colluvions, d'alluvions et de sédiments fluvio-glaciaires. D'autres sites fossilifères risquent de se trouver là où les cours d'eau fluvio-glaciaires traversent des colluvions déposées avant le début de la Glaciation de McConnell.
ZUSAMMENFASSUNG Säugetier-Stratigraphie und Sedimentologie im Wisconsinium am Ketza River, Yukon Territory. Reste von Mammut, Bison, Pferd, amerikanischem Elch, Hase, Eichhörnchen und Lemming aus dem mittleren Wisconsinium sind in Sedimenten, die stratigraphisch unter dem Till der McConnell-Vereisung des späten Wisconsiniums liegen, entlang des Ketza River-Tals gefunden worden. Diese knochenhaltigen Sedimente bestehen aus einem Komplex von Kolluvium, Alluvialfächern und glazi-fluviatilen Sedimenten. Ähnliche FossilFundstellen befinden sich wahrscheinlich da, wo glazi-fluviatile Wasserläufe auf BerghangAblagerungen treffen, die vor dem Beginn der McConnell-Vereisung abgelagert worden sind.

* Geological Survey of Canada Contribution No. 30989

Manuscrit reçu le 18 octobre 1989; manuscrit révisé accepté le 11 juin 1990 


\section{INTRODUCTION}

The unglaciated areas of Yukon Territory have yielded an impressive suite of Late Pleistocene mammalian remains (Harington, 1977, 1978, 1989). In contrast, glaciated areas of Yukon, particularly areas glaciated during the Late Wisconsinan age McConnell Glaciation (Bostock, 1966; Hughes et al., 1969) have been unproductive.

In 1986, a bison thoracic vertebra was discovered in gravel beds exposed along an exploration road above Ketza River in east central Yukon (Figs. 1 and 2). Preliminary excavation indicated a potentially productive Middle Wisconsinan mammalian fossil site. The age estimate was confirmed by an accelerator mass spectrometry radiocarbon date on a Bison sp. radius of 26,350 $\pm 280 \mathrm{yr} \mathrm{BP}$ (TO-393). An extensive excavation was carried out the following year, and all fossil bones and teeth (mammoth, bison, hare, ground squirrel, lemming, small horse, and moose) were turned over to the second author for identification. Additional horse bones and teeth were recovered when both authors visited the site in August 1988 (Table I).
This paper details the fauna identified from the Ketza River site and the stratigraphy and sedimentology of the site. Since this is the only known Middle Wisconsinan fossil site from within the area of the Yukon covered by the Cordilleran Ice Sheet during McConnell Glaciation, the authors hope that an understanding of the sedimentology of the enclosing deposits may expedite the discovery of similar sites elsewhere within this region.

\section{SETTING}

The Ketza River site is located on a hillside on the northeast flank of the Ketza River valley, $40 \mathrm{~m}$ above the river and $30 \mathrm{~km}$ southeast of the settlement of Ross River (Fig. 1). Ketza River follows the Tintina fault which separates terrain of contrasting physiography and geology. To the southwest, Pelly Mountains are composed of complexly faulted and folded Paleozoic cherts, carbonates and clastics which have been intruded by Mesozoic quartz monzonite (Tempelman-Kluit, 1977). To the northeast, Tintina Trench is underlain by schist of uncertain age. During Eocene time, likely under the impetus of right lat-

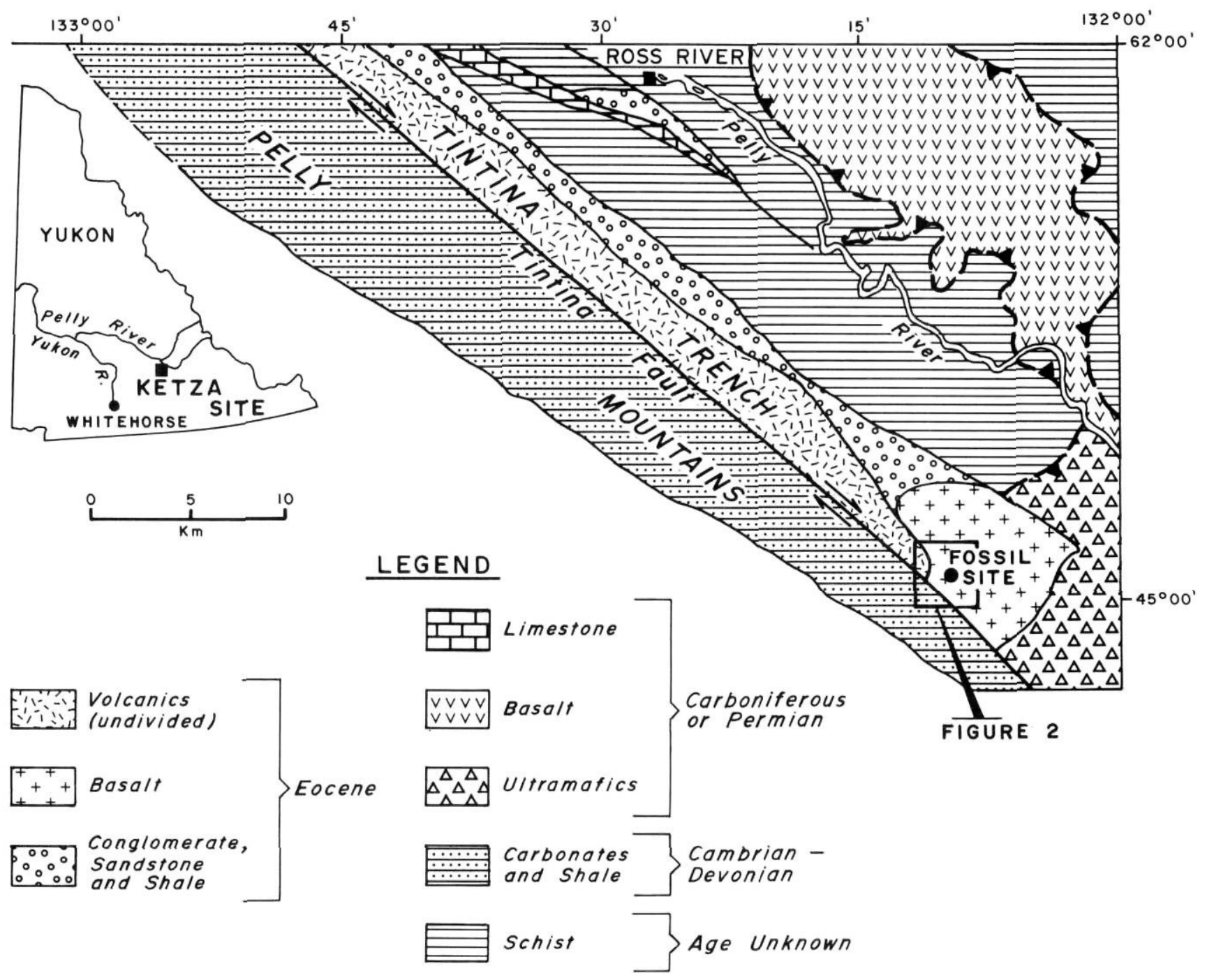

FIGURE 1. Location and generalized geology of the Ketza River site. Localisation et géologie sommaire du site de Ketza River. 


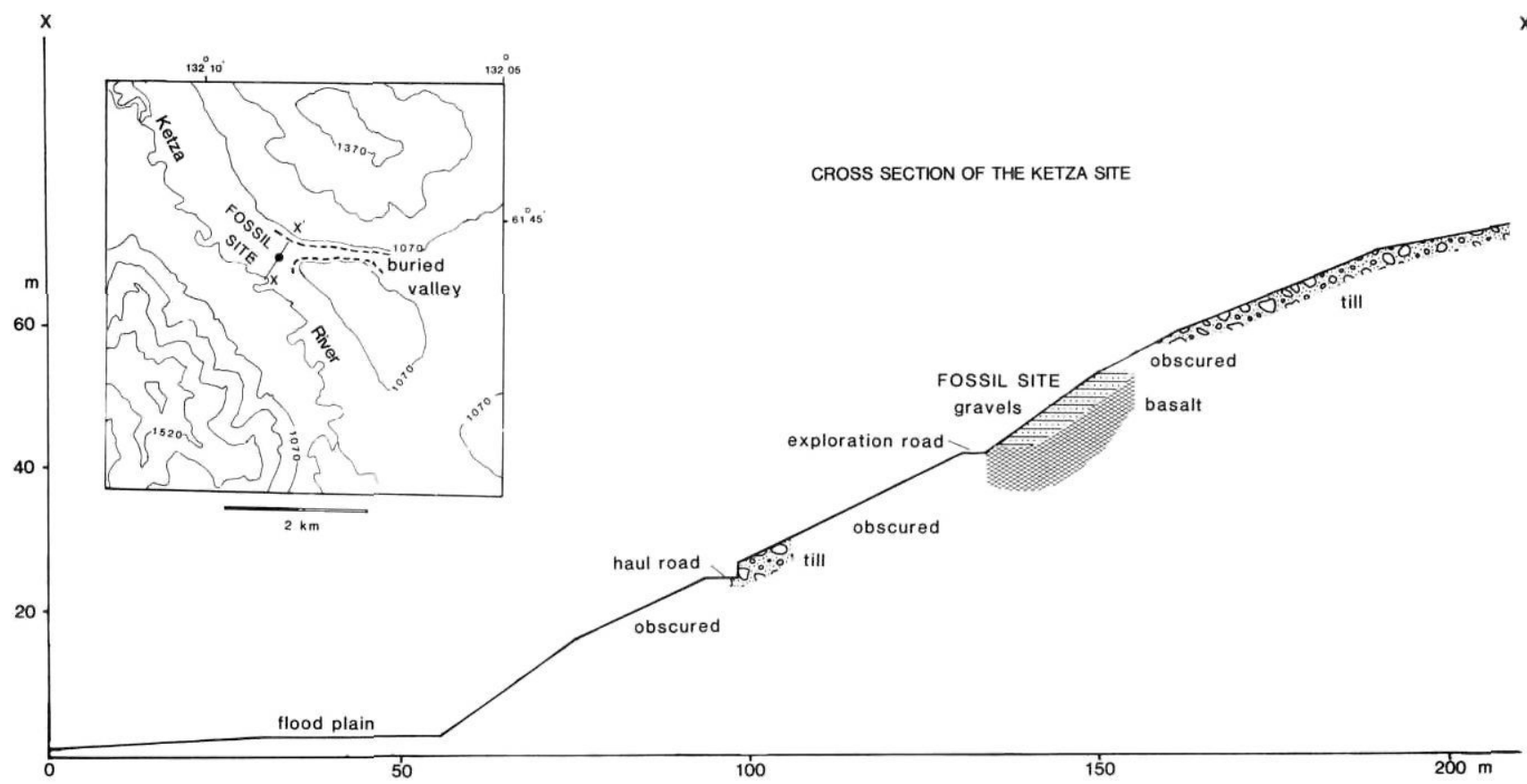

FIGURE 2. Topography and general stratigraphy of the Ketza River site.

eral movement along the Tintina fault, the schist underlying Tintina Trench was faulted into many pull-apart basins which were filled by coal-bearing clastic sediments and bimodal volcanics (Hughes and Long, 1980; Jackson et al., 1986; Pride, 1988). The bedrock immediately adjacent to and below the gravels at the Ketza site is poorly exposed pillow basalts and basalt flows of one of these basins. The site lies well within terrain glaciated by the Selwyn lobe of the Cordilleran Ice Sheet during McConnell Glaciation (Hughes et al., 1969).

The vegetation of the area is presently boreal forest dominated by white spruce (Picea glauca), black spruce ( $P$. mariana), willow, (Salix sp.), and poplar (Populus sp.). Grasslands exist locally on exposed south facing slopes. Permafrost is discontinuous in the area and it is most extensive along valley bottoms and north facing slopes.

The gravels were originally exposed in a road cut along an exploration access road. The exposure was originally nearly vertical but by 1986 it had wasted back and a thick wedge of sloughed sediment had formed at its base. It was largely overgrown by grass and small trees when discovered.

\section{SITE STRATIGRAPHY}

Figures 2 and 3 depict the geology of the site. The gravels and coarse basaltic sands, which yielded the mammalian remains, rest unconformably upon basalt and are capped by a diamicton interpreted to be a till deposited during the Late Wisconsinan McConnell Glaciation. The radiocarbon date of $26,350 \pm 350 \mathrm{yr}$ BP on the Bison radius documents the Middle Wisconsinan age of the enclosing sediment and is presently the youngest radiocarbon date from below glacial sediments in central Yukon. The overlying diamicton is identified as a till based upon the following criteria:
Topographie et stratigraphie générale du site de Ketza River.

1. Content of abundant striated, polished, and flatiron-shaped stones of erratic lithology from along Tintina Trench to the southeast and from Pelly Mountains to the south (Table II).

2. Truncation of underlying units along an erosional contact marked by shearing and striations where such contacts are exposed elsewhere in the area.

3. Generally continuous cover over the glacially streamlined uplands within Tintina Trench (Jackson, 1986). Only on steeper slopes is it discontinuous and reworked by slope processes.

\section{METHODS}

The site was exposed systematically through manual excavation of a succession of benches at approximately $1 \mathrm{~m}$ (vertical) intervals. Each shovelful of excavated gravel and sand was inspected for fossil material during initial exposure. The stratigraphy and sedimentology of the site were described as the site was exposed and the most productive beds were identified. The beds were subdivided according to facies types and contact relationships. One unit, traceable across the site, was arbitrarily numbered 100; beds above decreased and those below increased in number from 100 (Fig. 3). Once the site was exposed, productive gravel beds were excavated by trowel and sandy beds by shovel and wet screening.

The Pleistocene mammal remains were found almost entirely in three units (Fig. 3): 105 (4\%), 106 (68\%) and 107 $(19 \%)$.

\section{FAUNA}

Faunal identifications by the second author are as listed in Table I. Since the specimens are so fragmentary, only the best 
TABLE

Fauna of the Ketza River fossil site

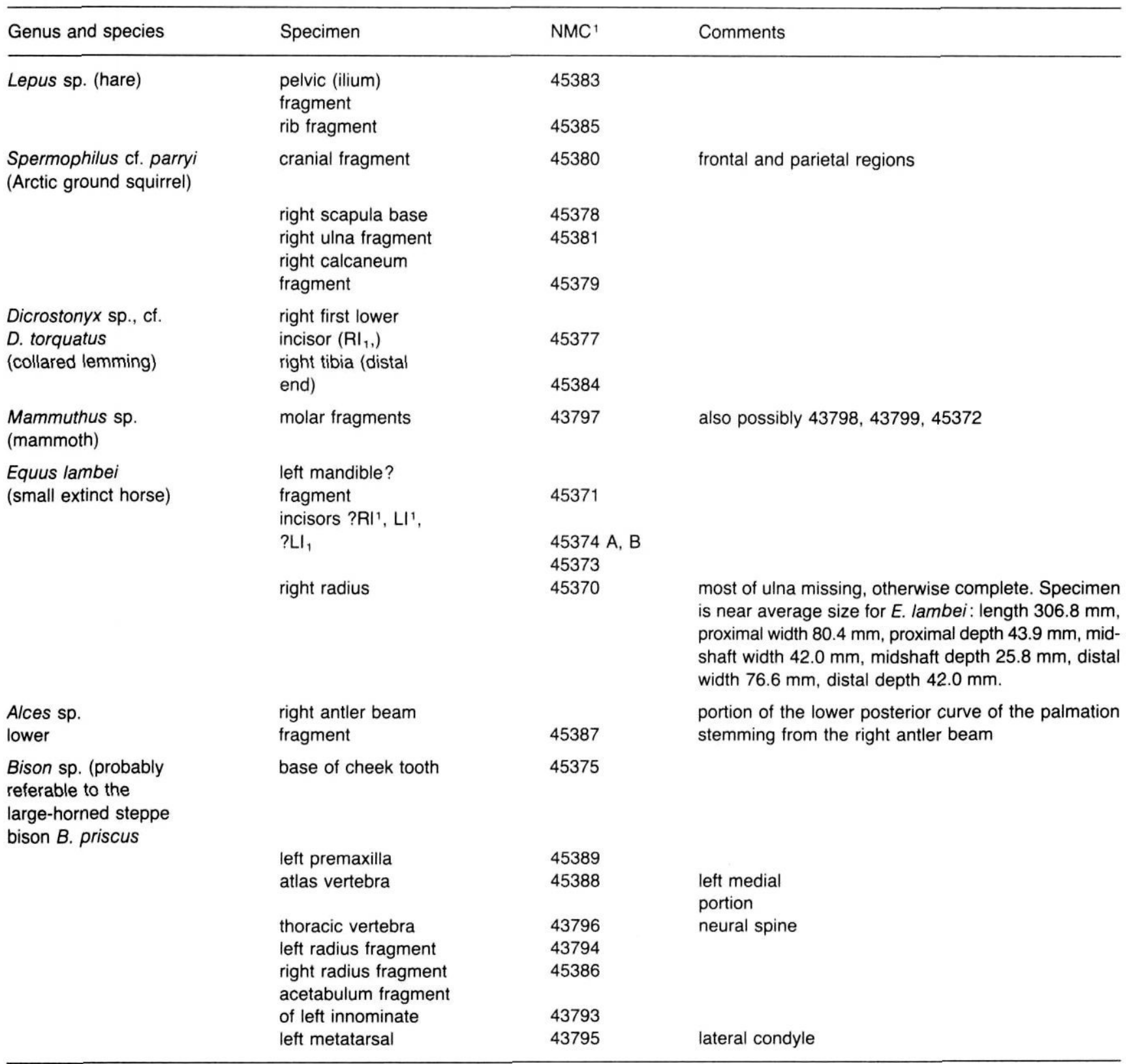

1 Canadian Museum of Nature catalogue numbers

preserved one, a radius of the small Yukon horse Equus lambei (Canadian Museum of Nature (NMC) specimen 45370), can be identified to species and measured (Fig. 4). All taxa reported from this site have been found previously in Yukon Pleistocene deposits (Harington, 1977).

The fauna at this site is best compared to those at Dublin Gulch (near Mayo) and Big Creek (near Carmacks), which are considered to be of Middle Wisconsinan age based on associated radiocarbon dates (Harington, 1989; Table II). Although Dublin Gulch and Big Creek lack the smaller mammalian com- ponent (except for the snowshoe hare, Lepus americanus from Big Creek), presumably because the fossil-bearing deposits were not wet-screened, mammoth (woolly mammoth, Mammuthus primigenius), horse (small Yukon horse, Equus lambei), bison (large-horned bison, Bison priscus) and moose (Alces sp.) have been recovered at both sites. The data from these three sites, albeit preliminary, suggest a continuity of widespread steppe-like grassland habitat in the central Yukon from nearly 50,000 to $10,000 \mathrm{yr}$ BP but with a stronger wetland component during the Middle Wisconsinan, as suggested by the presence of moose. 


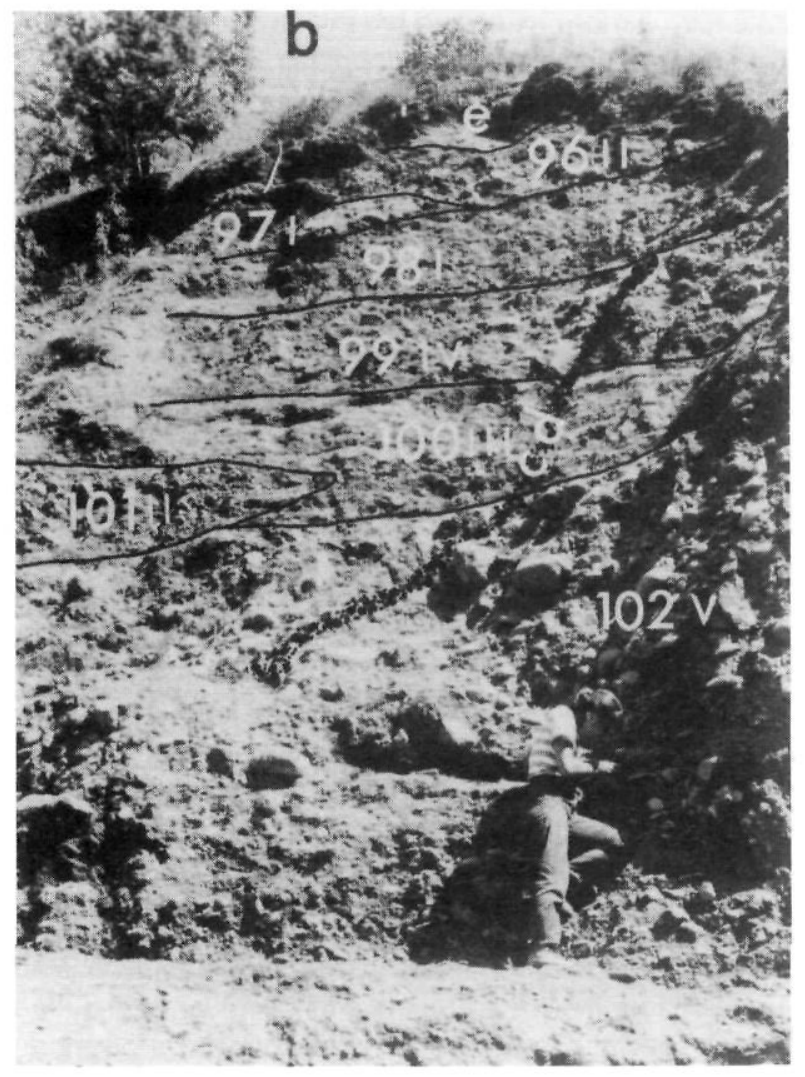

FIGURE 3. The Ketza River site following excavation: a) diagram showing the relative position of the composite views; b) upper portion of the exposure; $c$ ) lower portion of the exposure. Hindu-Arabic numbers are unit numbers and the Roman numerals are lithofacies designators described in the text.

Le site de Ketza River après excavation: a) diagramme montrant la position relative des éléments du montage; b) partie supérieure de la coupe; c) partie inférieure de la coupe. Les chiffres arabes représentent les unités, tandis que les chiffres romains désignent les lithofaciès décrits dans le texte.
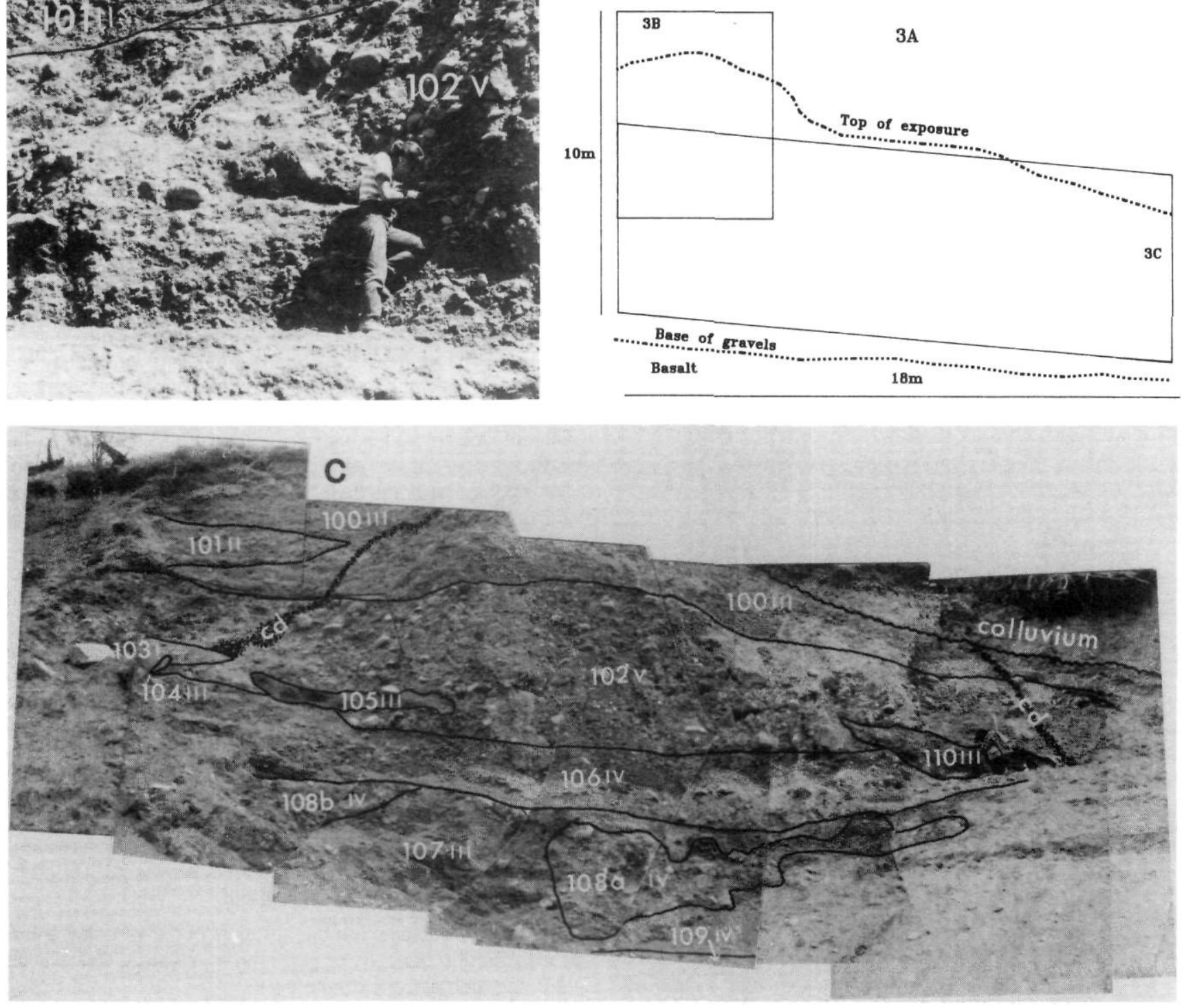

American moose (Alces alces) or giant moose (Alces latifrons) could be represented at the Ketza River site. Although the American moose prefer life in the boreal forest, or in the more heavily wooded, marshy parts of parkland regions, they are capable of moving into tundra areas (Banfield, 1974). Therefore, during Middle Wisconsinan time, it is not difficult to envisage American moose occupying forested wetland mar- gins in valley bottoms adjacent to drier steppe-like grasslands that dominated nearby uplands, and even moving out into more open country. A modern analogue is suggested by the extensive grassy areas amongst forest on the dry south-facing hillside near the fossil locality - the adjacent valley floor being dominated by forested wetlands. Perhaps under a cooler, drier climate that may have existed near the end of the Middle 

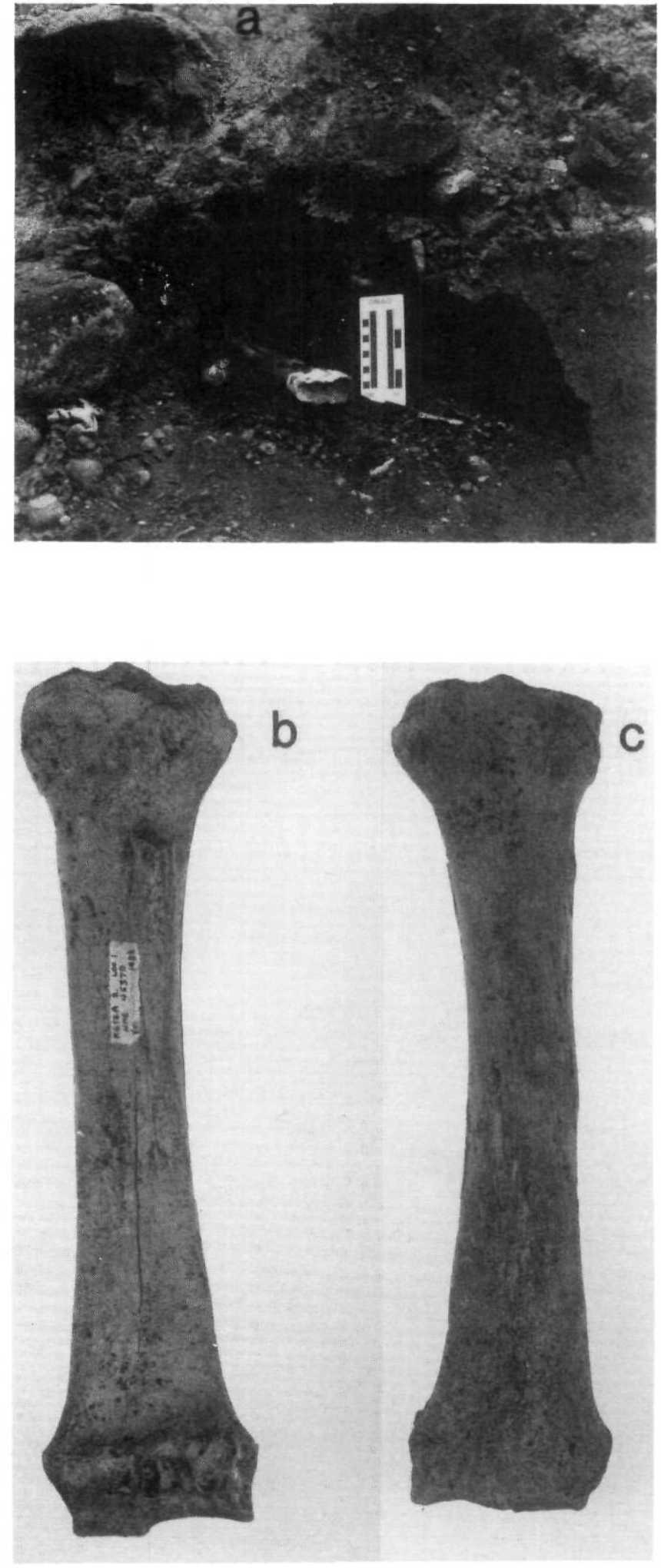

FIGURE 4. Right radius of Equus lambei (NMC 45370): a) in situ in unit 102; b) detail photo following cleaning: posterior view (most of ulna missing); c) anterior view. Maximum length: $308.8 \mathrm{~mm}$.

Radius droit d'Equus lambei (NMC 45370); a) in situ dans l'unité $n^{\circ}$ $102 ; b)$ détail après nettoyage: vue postérieure (plus grande partie du cubitus manquante); c) vue antérieure. Longueur maximale: $308,8 \mathrm{~mm}$.
Wisconsinan, a more extensive grassland would replace the forest on the slope, whereas the floodplain of the Ketza River would support the forested wetland preferred by moose.

Since moose remains have been found at all three Yukon sites considered to be of Middle Wisconsinan age, the paleoenvironmental interpretation mentioned above seems preferable to the alternative that the assemblage accumulated from succeeding environments: moose from boreal forest wetland type, and the rest from steppe-like landscape.

If the moose specimen represents a giant moose (Alces latifrons) - a species perhaps better adapted to open steppe-like or parkland regions (Harington, 1977; Sher, 1971; Giterman, 1973), the accommodation within drier habitat would have been easier. It is worth mentioning that a giant moose antler beam from Old Crow basin in the northern Yukon has yielded a radiocarbon date of $33,800 \pm 2000 \mathrm{yr} \mathrm{BP}(1-4229)$. If this date is correct, and not minimal, the Old Crow specimen indicates that giant moose survived until Middle Wisconsinan time in the Yukon (Harington, 1977). Alces latifrons in Eurasia is most characteristic of the Middle Pleistocene (Kurtén, 1968; Kurtén and Anderson, 1980).

\section{SEDIMENTOLOGY}

The preservation of the remains of a Middle Wisconsinan mammalian fauna in an area of Yukon glaciated during McConnell Glaciation requires an explanation. Furthermore, the bones and teeth recovered from this site occur in two quite different types of sediment (Fig. 3): interstratified thin lenticular beds of pebbly basaltic sand and diamicton (units 105 and 107), usually deformed, and thick bedded, coarse gravels with clast lithologies derived from elsewhere within Tintina Trench and Pelly Mountains (unit 106). The sizes of bone and tooth remains are often unrelated to the textures of enclosing sediments: although many fine bones of small mammals were obtained from sandy beds (units 105 and 107 (Fig. 3), they were also obtained from the coarse gravels of unit 106. Conversely, while many larger bones were found in gravelly unit 106, large incisors from $E$. lambei and molar fragments from Mammuthus sp. were found in sandy units 105 and 110 respectively.

In order to understand the sedimentary environments and history of the sediments that contain the fossil assemblage, the textures, bedding contacts, sedimentary structures and clast lithologies were studied in the field. Five lithofacies were identified and applied to the reconstruction of sedimentary environments. These are detailed in Table II.

The five lithofacies are the products of the interplay of the processes and deposits of glaciofluvial, colluvial and alluvial (fan) sedimentary environments.

Facies IV and V are characterized by poorly sorted, coarse, massive or disorganized gravels. The disorganized gravels are characterized by scattered, laterally discontinuous fining-up sequences, cluster bedforms, and coarse lags. The texture and sedimentary structures of these facies reflect flood discharge with rapid waning of flow. This discharge regime and sedimentary characteristics can be found in the proximal glaciofluvial channel environment at the margins of valley glaciers (Church and Gilbert, 1975; Boulton and Eyles, 1979). This environment 
TABLE ॥

Lithofacies and clast provenance

\begin{tabular}{ccccc}
\hline Facies & Thickness & Texture 1 & $\begin{array}{c}\text { Contact } \\
\text { relationships }\end{array}$ & $\begin{array}{c}\text { Sedimentary } \\
\text { structures }\end{array}$ \\
provenance
\end{tabular}

\begin{tabular}{|c|c|c|c|}
\hline $\begin{array}{l}\text { I Diamicton } \\
\text { (units } 97,98 \text {, } \\
103 \text { ) }\end{array}$ & $0-70 \mathrm{~cm}$ & $\begin{array}{l}\text { diamicton, clasts } \\
\text { to } 10 \mathrm{~cm} \text { but } \\
\text { commonly } 2 \mathrm{~cm} \\
\text { supported in a } \\
\text { silty sand matrix. }\end{array}$ & $\begin{array}{l}\text { scoured contact or boulder } \\
\text { lag along base, abrupt to } \\
\text { gradational contact with } \\
\text { overlying gravels. Unit } 103 \\
\text { is a clastic dike-source bed. }\end{array}$ \\
\hline
\end{tabular}

II Massive, sandy gravel (units 96, 100, 101)

\section{Stratified sand} and diamicton (units 100, 104, $105,107,110)$
$60-120 \mathrm{~cm}$

\section{sandy pebble} gravel, some clasts to $15 \mathrm{~cm}$.

$0-140 \mathrm{~cm}$

sand, pebbly sand, and sandy pebbly diamicton. erosional upper and lower massive contacts.

as above. Units 104, 105 , 110 are large contorted lenses. Unit 107 contains a contorted lens of facies IV (unit 108a). Unit 110 is a clastic dike source bed.

$50-100 \mathrm{~cm}$

poorly sorted sandy gravel. Largest clasts to $30 \mathrm{~cm}$ but clasts typically range from $2-10 \mathrm{~cm}$. upper and lower contacts are erosional.

(units 99, 106

108a and b, 109)

$100-200 \mathrm{~cm}$

$\checkmark$ Massive cobble gravel poorly sorted

boulder gravel with a sandy, pebbly matrix. Five largest clasts range from $30-55 \mathrm{~cm}$. lower contact is marked by boulder and cobble lags. Upper contact with facies III (unit 100) is abrupt and depositional. beds are lenticular and were originally horizontally stratified but now are folded and inclined with dips to $50^{\circ}$. Only unit 100 is undeformed. Locally interstratified with lenses of facies II. Bed thickness ranges from 0.5 to $6 \mathrm{~cm}$.

massive to crudely stratified. Crude bedding defined by fining-up sequences from coarse lags and by disorganized gravels with cluster bedforms. Crude bedding may grade to massive bedding over 1-2 $\mathrm{m}$ laterally.

massive with crude stratification defined by boulder lags and cluster bedforms. Contains contorted lenses of facies III. contains clasts of both underlying basalt and striated and polished lithologies from Pelly Mountains

lithic (basaltic) sand and gravel; $60 \%$ angular basalt.

sand and pebbles $>90 \%$ basalt from the underlying slope. Contains scattered deeply weathered granitic and metamorphic clasts.

clasts are $50 \%$ Pelly Mountains provenance (chert, carbonates, sandstone, conglomerate, and quartizite).

as above

\footnotetext{
1 clast dimensions measured along a-axis
}

is further indicated by the physiographic setting of the gravels and by their lithology. First, the fossil site is situated at $1170 \mathrm{~m}$ elevation, over $40 \mathrm{~m}$ above the floor of the Ketza River valley, at the mouth of a partly buried valley. This valley was a meltwater coulee which last conducted water at the close of McConnell Glaciation (Fig. 2). Facies IV and V gravels could only have been deposited if glacial ice were present to supply meltwater and sediment at the upstream end and to raise the base level at the downstream end of the meltwater coulee. Second, a proglacial environment of deposition is also indicated by the preponderance of Pelly Mountains lithologies in Facies IV and V gravels: the surrounding valley is cut entirely in basalts. The large quantity of coarse clasts of Pelly Mountains lithologies could have been deposited at this location only through deposition from outwash from an ice advance from Pelly Mountains.
Facies III is colluvium consisting of interstratified lenticular beds of basaltic diamicton and pebbly basaltic sand. It was derived almost entirely from local basaltic bedrock by weathering and short-distance transport by predominantly gravitational transport (solifluction and creep) with minor fluvial transport and by rills. These processes formed an apron of thin interdigitating lenses of pebbly lithic sands and diamictons along the margin of the meltwater coulee prior to deposition of Facies IV and V. Similar deposits have formed on basalt slopes in this area during the Holocene and are well exposed in roadcuts. Analogous deposits along the toes of the side slopes of meltwater coulees have been described by Osborn (1977) in the Alberta Foothills. The lenses of erratic pebbles present in these facies were likely derived from patches of older drift present on the side slopes of the coulee and concentrated in small fans along slope toes. We conclude that these slope 
processes were the primary agents responsible for burying animal remains and that Facies III was the primary source for these remains for the following reasons. First, the greatest diversity of bones and teeth were recovered from this facies: everything from rodent limb bones and skull fragments to horse teeth and mammoth molar fragments. Second, bones and teeth entrained in Facies IV and V gravels are always found near erosional contacts with Facies III units. It is likely, based upon this relationship, that the bones and teeth were eroded from facies III units and redeposited in Facies IV and V gravels.

Facies III units 104, 105, and 110 are clearly large blocks surrounded by Facies IV and V units. These units originated as blocks of colluvium which slid or toppled into adjacent outwash channels from the margins of the meltwater coulee during deposition of the Facies IV and V units and were buried within these facies. The abrupt and contorted contacts with surrounding sediment and disturbed internal bedding of these blocks are consistent with slump deposition into a rapidly aggrading meltwater channel. For example, Facies III unit 107 is the largest slump-block exposed at the site. Units 108a and b are former fills in channels cut into unit 107 prior to its detachment from the adjacent coulee margin (Fig. 3a). The subsequent failure and transport of unit 107 deformed it and units $108 \mathrm{a}$ and $\mathrm{b}$.

Facies II (units 96, 100, and 101) are poorly sorted massive, angular and locally derived gravels. They are characteristic proximal lithofacies of small fans (Jackson et al., 1987) probably built along the margins of the meltwater coulee after deposition of Facies IV and V.

Facies I consists of sandy diamictons. These contain significant contents of striated non-basaltic pebbles predominantly from Pelly Mountains. These were deposited as debris flows originating either from patches of drift on the adjacent slope or from an active glacier margin or stagnant glacial ice. The limited area of exposure does not permit elimination of any of these possibilities.

Facies III unit 110 and Facies I unit 103 were source beds for clastic dikes that cut overlying sediments up to and including unit 99. Injection of the dikes was most likely triggered by glacial overriding. The termination of the dikes at the top of unit 99 suggests that the contact with overlying unit 98 is erosional and that units 96-97 postdate the glacial loading episode that triggered the dike injection.

\section{PROPOSED SEQUENCE OF DEPOSITIONAL EVENTS}

Deposition of the sediments at the Ketza site began ca. 26,000 years ago when active colluvial processes on the north side of a then-inactive meltwater coulee resulted in burial of mammal remains in a colluvial mantle. Subsequently, a meltwater torrent, graded to glacial ice advancing out of Pelly Mountains during the onset of the McConnell Glaciation, flowed through the coulee. It cut into the slope deposits, deposited channel deposits (Facies IV and V units 108a, 108b, 106 and 102) and incorporated slump blocks (e.g. units 110 and 105), winnowed mammal remains from these slump blocks, and redeposited them into immediately adjacent channel deposits.
Ice loading during McConnell Glaciation caused clastic dikes to be injected from units 103 and 110 through overlying sediments. Subsequent erosion truncated the sequence and the clastic dikes along the top of unit 99 . This was followed by deposition of an alluvial fan composed of debris flow diamicton and basaltic gravel (units 97 and 96) mobilized from farther upslope. It is not clear from the exposure whether units 97 and 96 were deposited following the main advance of McConnell Glaciation or following an early stage advance and were subsequently overrun by the main McConnell advance.

\section{CONCLUSIONS}

The Ketza River site is particularly important because it is the most southerly of the main faunal localities recorded in Yukon, the only one found within the McConnell limit, and because wet-screening has helped to clarify the small mammalian component of the fauna.

The Ketza River site has yielded a Middle Wisconsinan assemblage of large and small mammals reflecting coexisting steppe-like and wetland environments or the cumulative record of succeeding environments. Preservation of mammal remains involved incorporation of them within colluvium followed by slumping and redeposition within glaciofluvial gravels. This was followed by further burial beneath fan sediments and overriding by glacial ice during McConnell Glaciation. The sedimentology of the site suggests that similar mammalian fossil remains are likely in pre-McConnell glaciofluvial deposits which are adjacent to and bury former hillslopes.

\section{ACKNOWLEDGMENTS}

The first author would like to dedicate this paper to the memory of Dr. Guy Lortie (1949-1988). His tragic death was a great loss to Quaternary research in Canada and a personal loss to all who knew him.

The fossil site was discovered by Brent Ward during his tenure as senior field assistant to the first author. Dave Dunkley assisted in the excavation of the site in 1987. Their help is gratefully acknowledged. This work and paper were aided greatly by a field visit and critical review by Steve Morison, Department of Indian Affairs and Northern Development, Whitehorse. Thomas D. Hamilton and Michael C. Wilson critically reviewed this text and their comments enhanced the clarity of the paper.

\section{REFERENCES}

Banfield, A. W. F., 1974. The mammals of Canada. University of Toronto Press, $483 p$.

Brayshaw, A. C., 1984. Characteristics and origin of cluster bedforms in coarse-grained alluvial channels, p. 77-85. In E. H. Koster, and R. J. Steel, eds., Sedimentology of gravel and conglomerates. Canadian Society of Petroleum Geologists, Memoir 10.

Bostock, H. S., 1966. Notes on glaciation in central Yukon Territory. Geological Survey of Canada paper 65-36, 18 .

Boulton, G. S. and Eyles, N., 1979. Sedimentation by valley glaciers; a model and genetic classification, p. 11-23. In C. N. Schluchter, ed., Moraines and varves, A. A. Balkema, Rotterdam. 
Church, M. and Gilbert, R., 1975. Proglacial fluvial and lacustrine environments, p. 22-100. In A. V. Jopling, A. V. and B. C. McDonald, eds., Glaciofluvial and glaciolacustrine sedimentation. Society of Economic Paleontologists and Mineralogists special publication no. 23.

Giterman, R. Ye., 1973. Vegetation of Pleistocene cold epochs of the Kolyma Lowland in connection with the problem of landscapes of polar Beringia, p. 65-68. In The Bering land bridge and its role for the history of Holarctic floras and faunas in the late Cenozoic. Academy of Sciences of the U.S.S.R., Far-Eastern Scientific Centre, Kharbarovsk.

Guthrie, R. D., 1985. Pleistocene paleontology, woolly arguments against the mammoth steppe - a new look at the palynological data. Quaterly Review of Archaeology, 6: 9-13.

Harington, C. R., 1977. Pleistocene mammals of the Yukon Territory. Ph.D. thesis, University of Alberta, Edmonton, 1060 p.

1978. Quaternary vertebrate faunas of Canada and Alaska. National Museums of Canada, Syllogeus Series 15, 104 p.

1980. Pleistocene mammals from Lost Chicken Creek, Alaska. Canadian Journal of Earth Sciences, 17: 168-198.

1989. Pleistocene vertebrate localities in the Yukon, p. 93-98.

In L. D. Carter, T. D. Hamilton and J. P. Galloway, eds., Late Cenozoic History of the Interior Basins of Alaska and the Yukon. United States Geological Survey, Circular 1026.

Harington, C. R. and Clulow, F. V., 1973. Pleistocene mammals from Gold Run Creek, Yukon Territory. Canadian Journal of Earth Sciences, 10: 697-759.

Hughes, J. D. and Long, D. G. F., 1980. Geology and coal resource potential of early Tertiary strata along Tintina Trench, Yukon Territory. Geological Survey of Canada, Paper 79-32, 21 p.
Hughes, O. L., Campbell, R. B., Muller, J. E. and Wheeler, J. E., 1969. Glacial limits and flow patterns, Yukon Territory, south of $65^{\circ}$ north latitude. Geological Survey of Canada, Paper 68-34, 9 p.

Jackson, L. E., Jr., 1986. Terrain inventory Finlayson Lake map area (105 G); Geological Survey of Canada, Open File 1379.

Jackson, L. E., Jr., Kostaschuk, R. A. and MacDonald, G. M., 1987. Identification of debris flow hazard on alluvial fans in the Canadian Rocky Mountains. Geological Society of America, Reviews in Engineering Geology, 7: 115-124.

Jackson, L. E., Jr., Gordey, S. P., Armstrong, R. L. and Harakel, J. E., 1986. Bimodal Paleogene volcanics near Tintina fault, east-central Yukon and their possible relationship to placer gold. Yukon Geology, 1: 139-147.

Kurtén, B., 1968. Pleistocene mammals of Europe. Weidenfeld and Nicolson, London, $317 \mathrm{p}$.

Kurtén, B. and Anderson, E., 1980. Pleistocene mammals of North America. Columbia University Press, New York, 442 p.

Osborn, G. D., 1977. Episodic alluviation in meltwater channels near Calgary, Alberta. Canadian Journal of Earth Sciences, 14: 1515-1520.

Pride, M. J., 1988. Bimodal volcanism along Tintina Trench, near Faro and Ross River. Yukon Geology, 2: 69-80.

Sher, A. V., 1971. Pleistocene mammals and stratigraphy of the northeast U.S.S.R. and North America. Nauka, Moscow, 310 p. (English translation published in the International Geology Review 16, 284 p., 1974).

Tempelman-Kluit, D. J., 1977. Geology Finlayson Lake and Quiet Lake map areas. Geological Survey of Canada, Open File report 436, 1: 250,000 maps. 